\title{
Effect of iron mining tailings as a red ceramic additive for decreased sintering temperature
}

\author{
Efeito do rejeito de mineração de ferro como \\ aditivo em cerâmica vermelha na diminuição \\ da temperatura de sinterização
}

Igor Brumano Coelho Amaral ${ }^{1}$, Bernat Vinolas Prat ${ }^{1}$, Arlete Barbosa dos Reis ${ }^{2}$

\author{
${ }^{1}$ Federal University of the Jequitinhonha and Mucuri Valleys. Institute of Science and Technology, CEP: 39100-000, \\ Diamantina, MG, Brasil \\ ${ }^{2}$ Federal University of the Jequitinhonha and Mucuri Valleys. Institute of Science and Technology. Department of \\ Chemical Engineering, CEP: 39100-000, Diamantina, MG, Brasil \\ e-mail: igor.brumano@ict.ufvjm.edu.br, bernat.vinolas@ict.ufvjm.edu.br, arlete.reis@ict.ufvjm.edu.br
}

\begin{abstract}
The ceramic materials industry includes the burning process at high temperatures in a way that the energy expense of the conventional methods of burning is very high. Using alternative raw materials shows a large potential in this process, such as wastes from other industrial processes, which may reduce the burning temperature of the ceramics, providing desirable characteristics with lower energy expense, as additives that have a high fluxes content, such as iron ore tailings. The waste used had its chemical composition analyzed by XRay Fluorescence, mineralogical composition analyzed by X-ray Diffraction and Granulometry by sieving and sedimentation. To study the properties of ceramic test pieces with addition of wastes, we used three different temperatures in the burning process to test if the use of the waste could improve its characteristics. We produced test pieces including a mixture of soil with 10 and $20 \%$ content of waste exposed to the sintering process at temperatures of 750,850 and $950^{\circ} \mathrm{C}$. To test the technological properties of the pieces we performed tests of linear shrinkage, loss on fire, coloring, water absorption, apparent porosity, compressive strength and scanning electron microscopy. The color of the test pieces was intensified, and the tested characteristics that showed improvements when the burning temperature decreased. However, at defined concentrations there was little variation in the test pieces produced with pure soil.
\end{abstract}

Palavras-chave: ceramics, waste, Anglo American.

\section{RESUMO}

A indústria de fabricação de materiais cerâmicos envolve o processamento de queima a elevadas temperaturas, de modo que o gasto energético das formas convencionais de queima é muito elevado. O uso de matérias-primas alternativas mostra um grande potencial nesse processo, como resíduos de outros processos industriais, que podem reduzir a temperatura de queima da cerâmica, fornecendo características desejáveis com menor gasto de energia, como aditivos que possuem alto conteúdo de fundentes, como rejeitos de minério de ferro. O rejeito utilizado teve sua composição química analisada por Fluorescência de Raios-X, mineralógica por Difração de Raios-X e granulometria por peneiramento e sedimentação. Para estudar as propriedades de corpos de prova cerâmicos com adição de rejeitos, eles foram queimados a três temperaturas diferentes de modo a avaliar se o uso do rejeito poderia proporcionar melhoria nas características. Foram produzidos corpos de prova contendo uma mistura de solo com teor de rejeitos de 10 e $20 \%$ expostos ao processo de sinterização às temperaturas de 750,850 e $950^{\circ} \mathrm{C}$. Para avaliar as propriedades tecnológicas das peças foram realizados ensaios de retração linear, perda ao fogo, coloração, absorção de água, porosidade aparente, resistência à compressão e microscopia eletrônica de varredura. Foi constatado que a coloração dos corpos de prova foi intensificada quando houve diminuição da temperatura de queima. Contudo, nas concentrações definidas houve pouca variação quanto aos corpos de prova produzidos com solo puro.

Keywords: cerâmicas, rejeitos, Anglo American. 


\section{INTRODUCTION}

For the abundance of raw materials and territorial extension, Brazil has a strong presence in the ceramic materials industry as one of the largest producers and consumers, representing 1\% of the national GDP (gross domestic product), where the red ceramic sector represented in which $40 \%$ [1]. Ceramic materials are compounded of inorganic and non-metallic materials, in the form of oxides, which go through molding and heat treatment at high temperatures, around $1000{ }^{\circ} \mathrm{C}$. The main helpful aspects of ceramic materials are its high strength and durability, diversity of products, low cost, ease of execution and maintenance, resistance to fire propagation and high availability in the market. However, the energy expense in the production process of these materials is very high, for the conventional sintering processes [2, 3, 4]. In addition, we connect the growth of the red ceramic industry to the use of abundant and low cost natural resources, generating many solid wastes that were first discarded without the preview of possible environmental impacts [5]; in this context, we show the preservation of the clay deposits through the residues incorporation in the ceramic mass as a helpful way of providing sustainability to the red ceramic industry [6].

However, taking into account the repair of environmental damage, the red ceramic sector stands out as to the possibility of using wastes from various industries, such as textile sludge [7], sludge from water treatment plants [8, 9], waste of gemstones [10], quartzites [11] and from basalts [12], ash from solid waste [13] and others, for high production volume and low technological requirements for raw materials.

The mining sector also has great economic relevance and wealth generation, although the destination of the waste from the ore exploration and processing has brought environmental concern. The ores explored in Brazil have various structures, given their different conditions of metamorphism, tectonism, weathering to which they were submitted in their genesis, originating ores with different constituents, morphology, dimensions, etc. In this way, researchers seeks safer destinations and with more positive impacts in the region where are the mining, aiming at the noblest destination for several types of waste to reduce the number and volume of tailings dams, an important criterion for judging the environmental performance of companies [15]. Therefore, iron ore tailings are viable for incorporation into low-grade ceramic masses for their mineralogical composition, of silicates, iron oxides, alumina and other minor minerals, which may have an important role in the increased mechanical resistance at lower burning temperatures.

In the ceramics manufacture, the sintering or burning stage to which we submit the mass is given by the transformations carried out with the use of thermal energy, in which the removing process of the remaining moisture from the drying phase occurs. Sintering is an irreversible process, in which flaws committed in previous steps become clear [16]. For red ceramic materials manufacture, we used temperatures around $950^{\circ} \mathrm{C}$ [17]. The three stages that make up the burning stage are the pre-sintering, when we eliminated organic matter and gases from the oxidation of raw materials, and must occur with slow heating of the ambient temperature to the desired temperature; sintering, time in which the furnace remains at the isothermal stage, in which part of the material goes through the melting process, penetrating the pores of the mass; and cooling, done gradually, occurs when the molten phase solidifies into a stronger and denser material. During sintering, several physical and chemical processes occur in the ceramic mass as: the loss of mass, formation of glassy phase and new crystalline phases and welding of the grains. The alkali minerals present in the raw materials (ilite, feldspar etc.) form the liquid phase that penetrates the pores of the mass, with the viscosity reduced by the increment in temperature, being eliminated by capillarity. For a good burning process of the clays, we recommended temperatures between 900 and $1000^{\circ} \mathrm{C}$, from $1150^{\circ} \mathrm{C}$ there is a great change in the parts, with a marked decrease in the rate of shrinkage, absorption and apparent porosity [18]. The iron, which provides reddish coloration to the ceramic mass, is released at about $900^{\circ} \mathrm{C}$ in the form of hematite.

The main metal oxides present in the clays are iron oxides I and II (ferric or hematite $-\mathrm{Fe}_{2} \mathrm{O}_{3}$ and ferrous - $\mathrm{FeO}$ ), magnetite $\left(\mathrm{FeO} . \mathrm{Fe}_{2} \mathrm{O}_{3}\right.$ or $\left.\mathrm{Fe}_{3} \mathrm{O}_{4}\right)$, limonite (iron hydroxide - $\left.\mathrm{Fe}(\mathrm{OH})_{3} \cdot \mathrm{nH}_{2} \mathrm{O}\right)$, goethite $(\mathrm{FeOOH})$, anatase (titanium dioxide - $\left.\mathrm{TiO}_{2}\right)$, ilmenite $\left(\mathrm{FeO} . \mathrm{TiO}_{2}\right)$ and others. Some researches demonstrate the effect of these oxides in the color change of the post-burning product. Oxidation of hematite and magnetite provide red and black color, and reduction of refractoriness found in materials for ceramic tiles in of 8 to $10 \%$ contents $[11,19,20]$. The quantity of the hematite and anatase should be bigger than $2 \%$ so that ceramic products have a reddish color, otherwise they will have a clear and whitish look. However, excessive anatase in the ceramic masses also brings the product to a grayish color [17]. Though, high levels of iron oxides may lead to former black heart, darkened region inside the post-burning products that causes swelling and pyroplastic deformations and titanium dioxide contents intensify the color provided by oxidation of hematite and magnetite [21].

Considering the soil used as a raw material for red ceramics, made up of hydrated aluminosilicates and low hematite content with low granulometry, we can use this process for incorporation of iron ore tailings 
[22]. In this way, conducted some studies to analyze the effects of this addition on ceramic products [23, 24]. Addition of melting material to ceramic is able for temperature decrease required to form liquid phase during the burning process. Then, the focus of this research is to examine the effect of the iron ore tailing used as an additive to reduce the red ceramic materials sintering temperature, also analyzing the esthetic effect of this addition as an intensifier of the red color of the product.

\section{MATERIALS AND METHODS}

Materials used: we collected the soil sample from the feeder coffin of the company Cerâmica Rio Paraúna, in Presidente Juscelino's city, and packaged in $5 \mathrm{~kg}$ bags. The residues used in this research come from an iron mining, collected from the Minas-Rio processing plant of the Anglo-American mining company, in Conceição do Mato Dentro's city. We extracted three gallons of 20 liters having a suspension mixture of the cyclone system in water overflow (red mud), we separated from which residues mass for the samples preparation after kiln-drying LUCA- 82 at $40^{\circ} \mathrm{C}$ brand. As the particle size of the residue after drying was a tiny reddish powder, and we don't requested any grinding or sieving for uniformity of the particles.

Characterization of the raw materials: we characterized the raw materials from the granulometric analysis by sieving and sedimentation process, checking the proportion between the granulometric bands according to test procedures DNER 051/94 [25]. We analyzed crystalline phases of the soil and waste samples by X-ray diffractometry (XRD) of the powder handling a Rigaku diffractometer, D/MAX Ultima Plus model, with copper tube $(\lambda=1.541838 \AA), 40 \mathrm{kV}$ of tension and $30 \mathrm{~mA}$ current, belonging to the X-Ray Diffraction Laboratory/Mineral Technology Service - SETEM. We performed the scans in range of 0 to $80^{\circ}$ $(2 \theta)$, with a $4^{\circ}(2 \theta) \min ^{-1}$ velocity. To determine the chemical composition of materials with grain size $<75$ $\mu \mathrm{m}$ we use X-ray fluorescence by energy dispersion using a Shimadzu EDX-720 spectrometer, identifying chemical elements with atomic number between sodium $(Z=11)$ and uranium $(Z=92)$, in the LIPEMVALE/UFVJM Multiuser Laboratory.

Formulation of the masses: the project of the experiment considered the variables involved in the manufacture process of test pieces: residue's percentage added to soil and the burning temperature. We used percentages of 10 and $20 \%(\% \mathrm{~m} / \mathrm{m})$ of the analyzed residues in partial replacement of clay amount present in the mass and test pieces without the residue addition to test the materials' properties produced with only soil. We established three burning temperatures $\left(750,850\right.$ and $\left.950^{\circ} \mathrm{C}\right)$, and we established the test pieces' nomenclature according to the variables considered, using the letter $\mathrm{F}$ followed by residues' percentages in each formulation and the letter Q followed by the burning temperature. For example, the F0Q750 test piece has $0 \%$ mass residue, and we burned it at $750{ }^{\circ} \mathrm{C}$, and so on.

Test pieces' conformation and sintering: we did the conformation of ceramic mass by the pressing process in a cylindrical mold $60 \mathrm{~mm}$ high and $30 \mathrm{~mm}$ in diameter, with a pressure of $20 \mathrm{MPa}$, and moisture contend of $10 \%$. We carried out drying process in a kiln, Lucadema model and LUCA-82 brand at $100 \pm$ $5^{\circ} \mathrm{C}$ for 24 hours. We burning it in a Magnu's muffle at a rate of $15^{\circ} \mathrm{C} / \mathrm{min}$ until the first stage $\left(1 \mathrm{~h}\right.$ at $\left.600^{\circ} \mathrm{C}\right)$ and $15^{\circ} \mathrm{C} / \mathrm{min}$ until the second burning stage (30 min at the desired temperature). The cooling performed in a slow and natural way, turning off the kiln at the ambient temperature.

Test pieces' characterization: after the test pieces sintering, we performed some tests to evaluate the physical and mechanical properties of the ceramic products: drying linear shrinkage (LS), burning LS and total LS, water absorption (WA), loss on fire (LF), apparent porosity (AP), compressive strength module (CSM), coloring and scanning electron microscopy (SEM).

\section{RESULTS AND DISCUSSIONS}

In Figure 1 we show the dry powder samples of the soil and of the residue after passing through the 35 mesh sieve and the formulations after mixing the clay with 10 and $20 \%$ of residue. It is possible to perceive already the tonality variation of the formulations. 

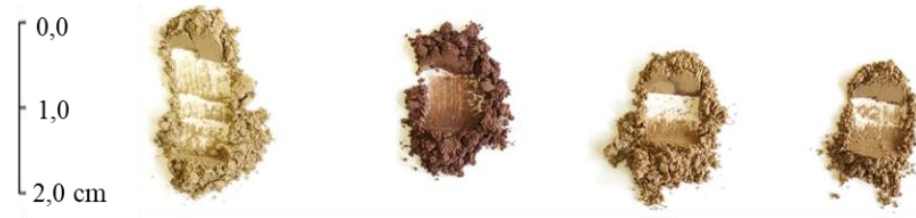

Soil

Residue

$10 \%$

$20 \%$

Figure 1: Samples of the soil, the residue and the formulations with 10 and $20 \%$ of residue

The soil's granulometric composition showed $22.9 \%$ of clay, $49.4 \%$ of silt and $27.7 \%$ of sand, and the waste, $1.2 \%$ of clay and $98.8 \%$ of silt. Thus, we observed a highest clay contend in soil sample, while the waste did not present any sand contend. The mineralogical composition by XRD test (Figure 2) showed presence of quartz $(63.4 \%)$ and kaolinite (36.6\%) in the soil sample, and hematite (48.4\%), quartz $(41.4 \%)$, goethite $(4.3 \%)$ and $5.9 \%$ of amorphous phase in the waste sample.
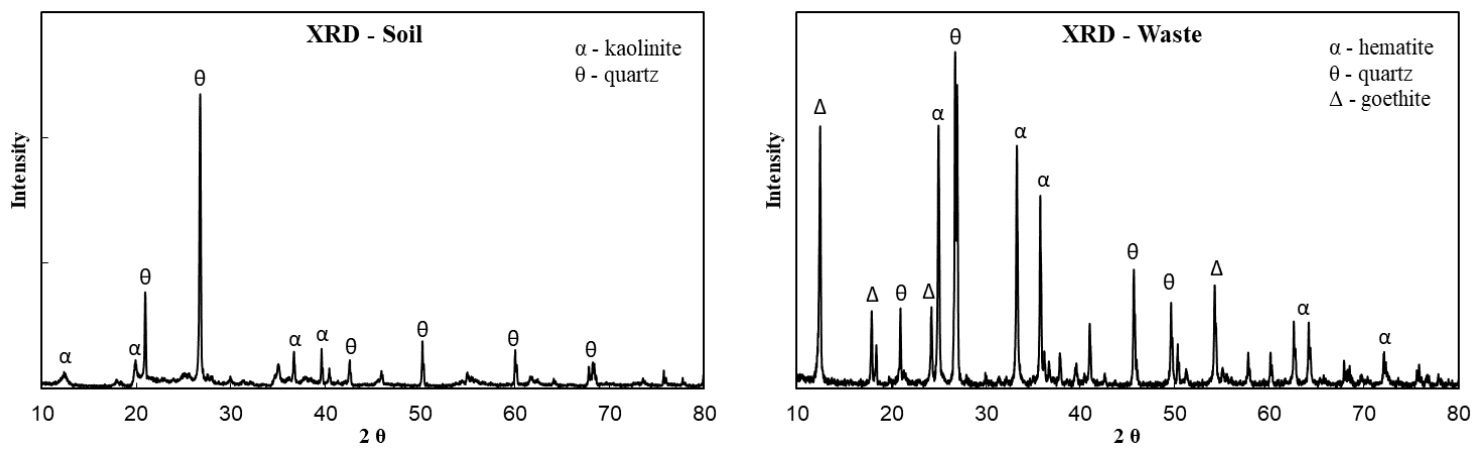

Figure 2: Diffractograms of soil and waste samples.

We present chemical analysis by RXF in Table 1.

Table 1: Soil and waste samples chemical composition

\begin{tabular}{l|l|l|l|l|l|l|l|l}
\hline \multicolumn{2}{l|}{ ÓXIDOS } & $\mathrm{SiO}_{2}$ & $\mathrm{Al}_{2} \mathrm{O}_{3}$ & $\mathrm{~K}_{2} \mathrm{O}$ & $\mathrm{Fe}_{2} \mathrm{O}_{3}$ & $\mathrm{TiO}_{2}$ & $\mathrm{CaO}$ & OTHERS \\
\hline \multirow{2}{*}{$\%$ in mass } & Soil & 51.31 & 36.96 & 5.07 & 4.84 & 1.2 & 0.46 & 0.16 \\
\cline { 2 - 9 } & Waste & 28.04 & 26.23 & 1.68 & 43.5 & 0.06 & - & 0.49 \\
\hline
\end{tabular}

The high iron contend in the tailings is a sign that its use as an additive should be restricted to smaller concentrations, showing that levels above $10 \%$ would not yield good results.

After the manufacture processes of test pieces, we arranged the properties investigated according to three sintering temperatures used. As for linear shrinkage (LS) of test pieces, we expected a gradual increase with the increase of temperature, which we can get in all formulations (Figure 3), with small variations between them at the same temperature. Although linear shrinkage of burning (LSB) reached a maximum value of $4.0 \%$, being a good range between 1.5 and 3.0\% [19] and the ideal found below 1.5\% [11]. Therefore, the use of the waste as an additive had a positive effect at temperatures of 850 and $950^{\circ} \mathrm{C}$ and, even though LS increased to $750{ }^{\circ} \mathrm{C}$, there was no substantial increase of this characteristic, since this is because of the expansion reduction of the test pieces subjected to this temperature. 

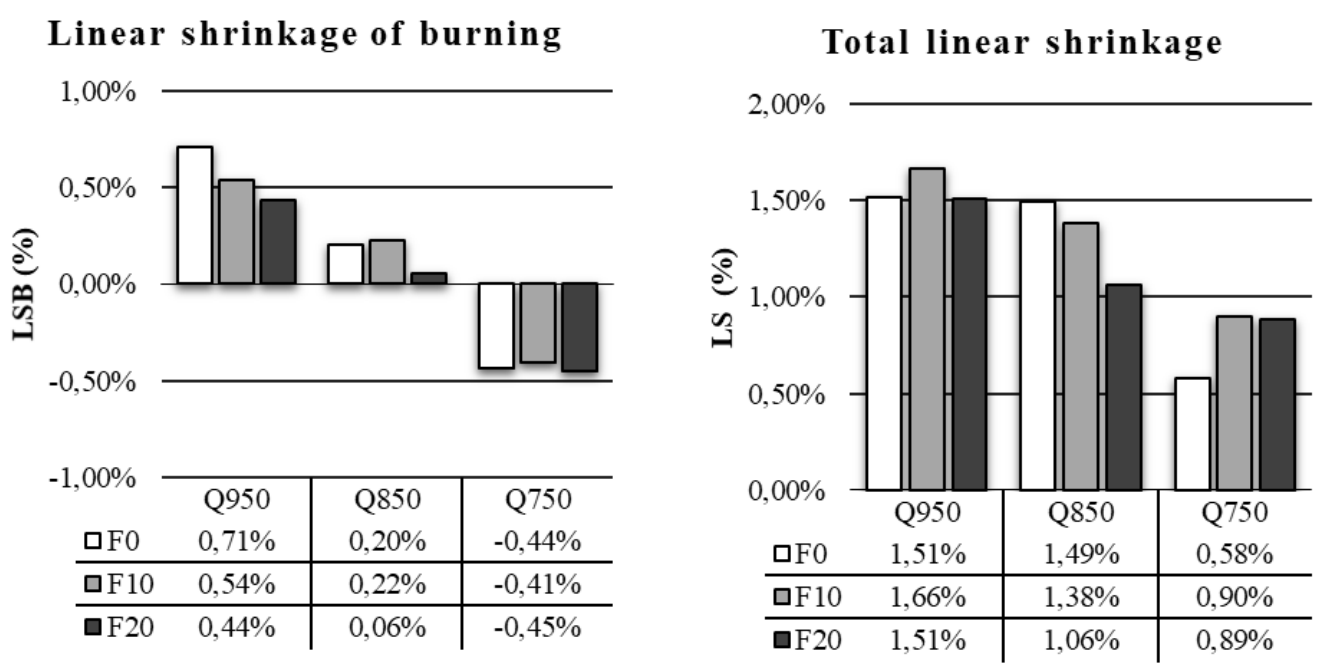

Figure 3: Linear shrinkage and total linear shrinkage by burning temperature.

The loss on fire (LF) of the test pieces is because of loss of coordinated and adsorbed waters, hydroxyls of the clay minerals $\left(\mathrm{Al}(\mathrm{OH})_{3}\right.$ and $\left.\mathrm{Fe}(\mathrm{OH})_{3}\right)$, carbon and sulfur dioxides, organic matter and volatile components $[13,26]$. The LF decreased as the amount of residue in the ceramic mass increased (Figure 4), because of the lower amount of organic matter in the residue, which, added to the mass, contributed to the percentage decrease of this composition in the mass.

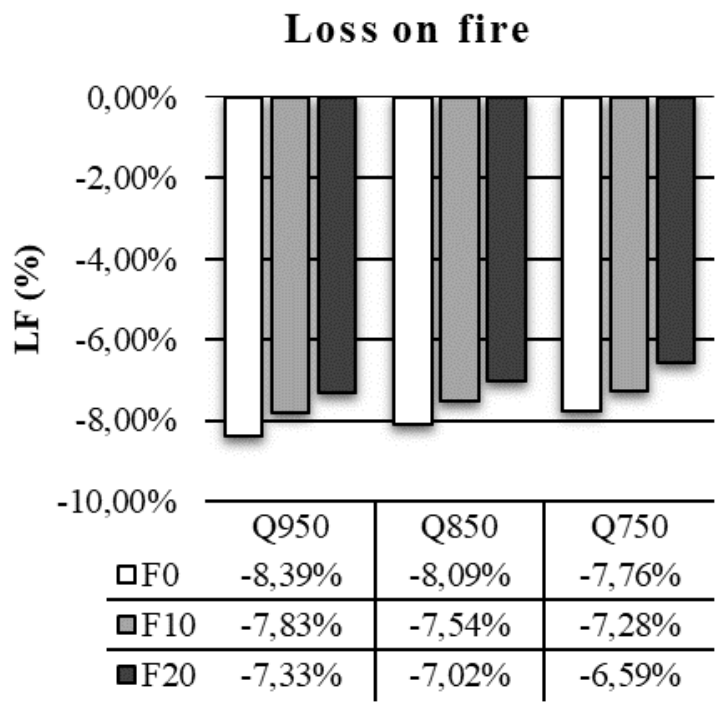

Figure 4: Loss on fire by burning temperature.

Table 2 illustrates the colors of the test pieces determined by using Münsell's letter [27]. The burning temperature's variation has changed little the coloring of the test pieces, however, the residue addition caused a brownish color from addition of $10 \%$ to the mass, becoming darker when it increased percentage of residue. This is because the coloring of these materials originates from the burning process and from the tenor of melting compounds (hematite) in the raw materials [28]. We show in Figure 5 the test pieces burned at $950^{\circ} \mathrm{C}$, for example.

Table 2: Coloring of the test pieces.

\begin{tabular}{lll}
\hline FORMULATION & COLOR & MÜNSELL \\
\hline F0Q750, F0Q850, F0Q950 & Light Red & 2.5 YR 6/8 \\
F10Q750, F20Q750, F10Q850, F10Q950 & Light Brown & 2.5 YR 4/6 \\
\hline
\end{tabular}




\begin{tabular}{lcc}
\hline F20Q850, F20Q950 & Brown & 2.5 YR 4/4 \\
\hline
\end{tabular}

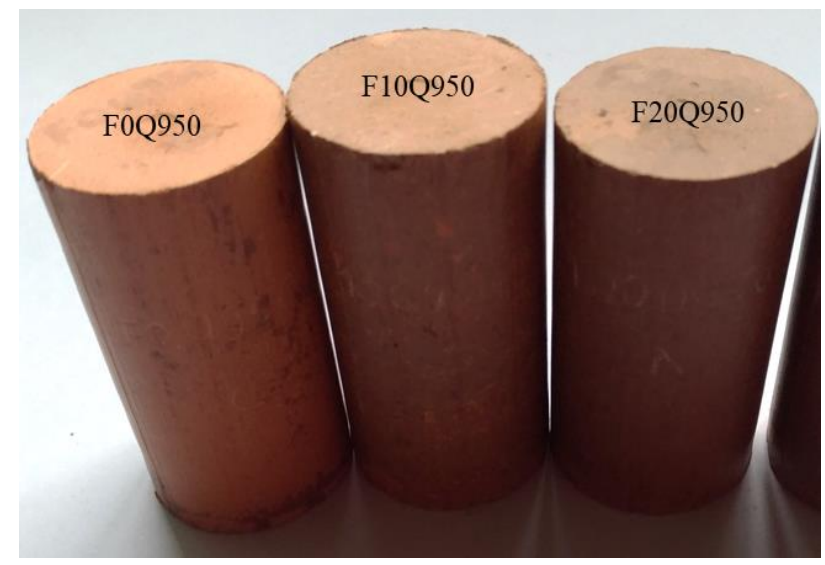

Figure 5: Tests pieces burned at $950^{\circ} \mathrm{C}$ with 0,10 and $20 \%$ of waste.

Analysis of water absorption (WA) results of the test pieces, shown in Figure 6, confirmed the hypothesis that the increase in the sintering temperature contributes to reduction of this rate, because of the densification that occurs in the material with the increasing the liquid phase formation. The increase of the waste tenor in the mass had very little influence on the water absorption of the products, although it was expected that the WA of the products would decrease with the increase of the melting tenor in the masses with residue addition and with the silica percentage reduction. The clay fraction decrease can explain this effect $(<2 \mu \mathrm{m})$ with increasing amount of residue. However, for WA, none of the formulations had restrictions for bricks manufacture, blocks (between $8 \%$ and $22 \%$ ) and tiles $(<20 \%)$.

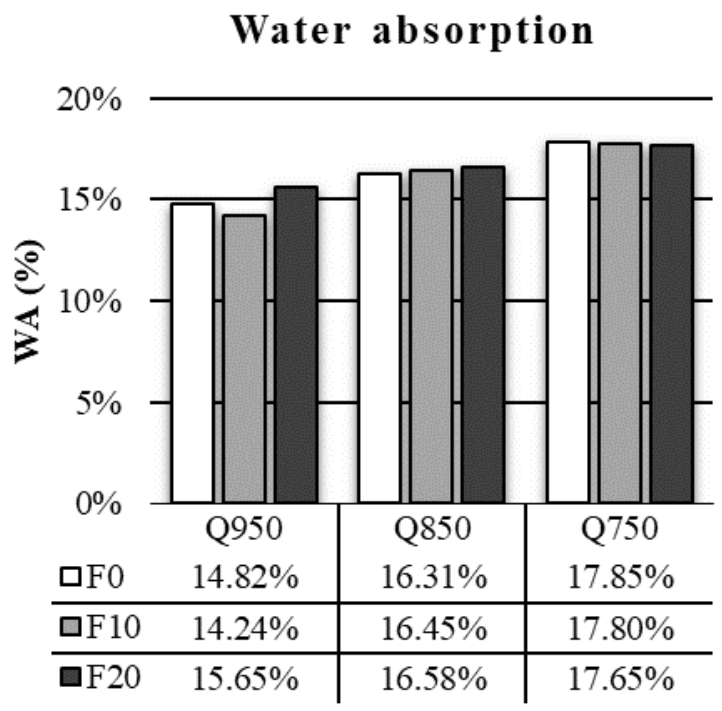

Figure 6: Water Absorption by burning temperature.

As well as WA results, apparent porosity (AP) decreased with increasing sintering temperature. The same happened with the residue addition to the ceramic mass, in which the higher the residue percentage, the greater the apparent porosity. The results shown in Figure 7 show apparent porosity values higher than 20\% for all test pieces, except for the formulation F10Q950. This is the limit value indicated for ceramic materials, in which above it, it is difficult to guarantee the mechanical integrity of the parts during transportation. 


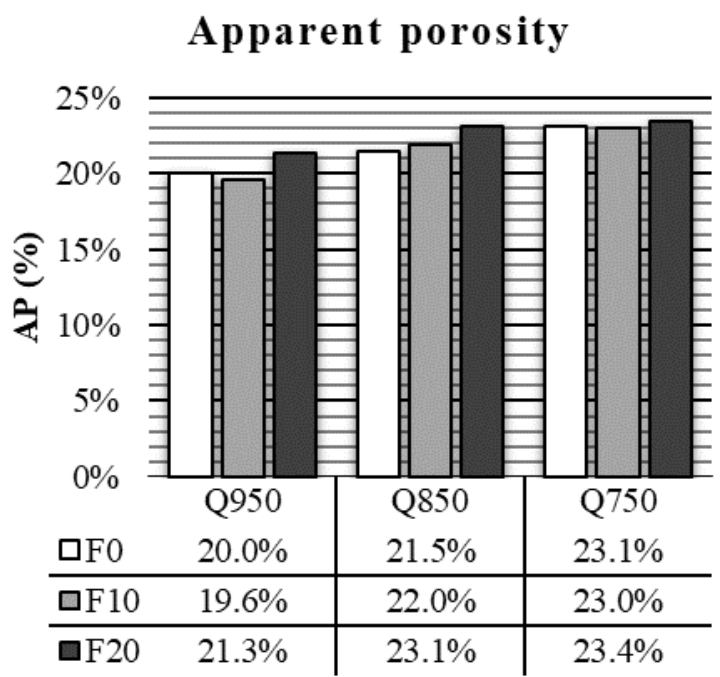

Figure 7: Apparent porosity by burning temperature.

Regarding the mechanical strength (Figure 8), residues incorporation to the mass highly reduced test pieces compressive strength, because of the increased porosity and water absorption in test pieces with higher residue contend. However, the minimum compressive strength for solid ceramic bricks, given by NBR 7170 [29], ranges from 1.5 to 4.0 MPa, while for ceramic blocks, NBR 15270 [30] defines the minimum values of compressive strength for blocks with horizontal holes of 1.5 MPa and 3.0 MPa for blocks with vertical holes. As for the structural blocks, according to NBR 15270 [30], the compressive strength should be higher than 3.0 MPa. Therefore, all test pieces showed compressive strength above the accepted limits.

\section{Compressive rupture module}

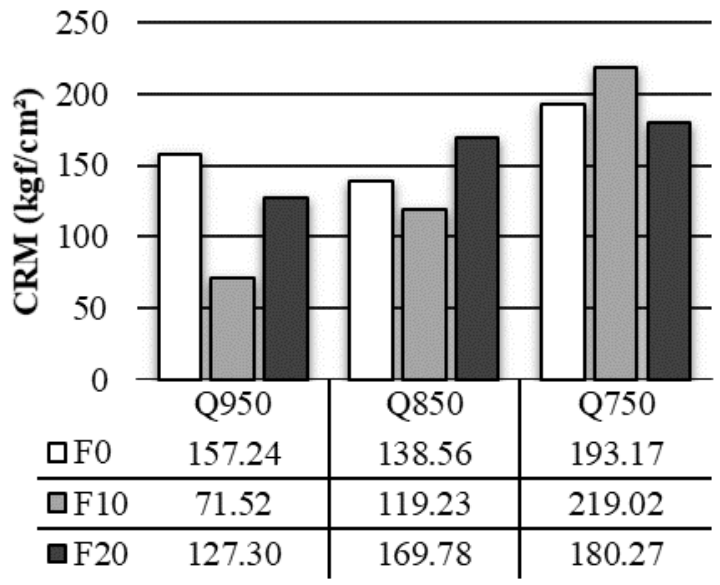

Figure 8: Compressive rupture module by burning temperature

In the images got by scanning electron microscopy (Figure 9) made from the fracture surface of sintered test pieces at $750^{\circ} \mathrm{C}$, we observed a well-formed surface, in which some cleavage planes specific to fragile ceramic rupture. The test pieces presented a smooth surface with few fine grains, but with surface pores of the order of micrometers, formed by evaporation of organic matter. 

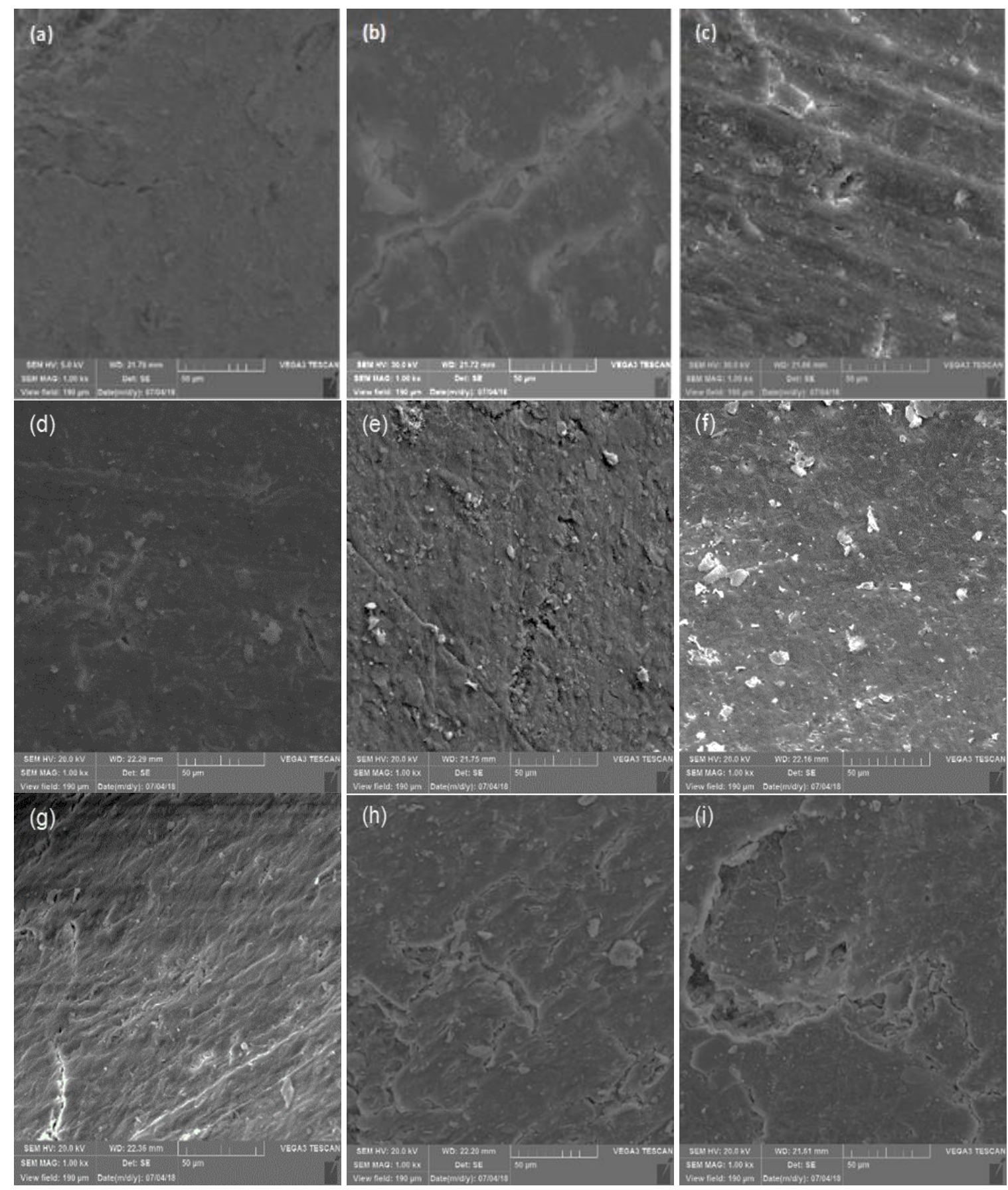

Figure 9: SEM (a) F0Q750 (b) F10Q750 (c) F20Q750 (d) F0Q850 (e) F10Q850 (f) F20Q850 (g) F0Q950 (h) F10Q950 (i) F20Q950

\section{CONCLUSIONS}

It improved few characteristics of ceramic test pieces with addition of the wastes. However, it can be said that the use of this iron ore tailing as a low grade additive reduced the minimum burning temperature to obtain characteristics close to the ceramic produced without additive at higher temperatures. Therefore, studies with lower waste contends and other burning cycles should be made, also to check if there is any influence of the additive on reducing the samples sintering time.

Linear shrinkage and loss on fire of pieces were the characteristics with more clear improvements and also showing color-enhancing effect of ceramic products. The best advantages of use of this waste as an additive are related to the product final aesthetics, which presented a more uniform coloration and a more intense red without stained appearance found in ceramics with partial or incomplete burning, strengthening the thesis that the iron mining tailing improved the sintering process because of an increase in melting contend in the 
mass.

\section{ACKNOWLEDGEMENTS}

LMMA financed by FAPEMIG (CEX-112-10), SECTES / MG and RQ-MG (FAPEMIG: CEX-RED-0001014). LIPEMVALE-UFVJM. GEPAEQ/UFVJM.

\section{BIBLIOGRAPHY}

[1] MACEDO, R.S. MENEZES, R.R., NEVES, G.A., et al., "Study of clays used in red ceramic", Cerâmica, v. 54, n. 332, pp. 411-417, Oct./Dec. 2008.

[2] RIVABEN, R. R., “Avaliação comporativa da sinterização de cerâmica vermelha em forno de microondas e forno convencional", Construindo, v. 10, n. 1, pp. 19-27, Jan/Jun. 2018.

[3] DUTRA, R. P. S., VARELA, M.L., NASCIMENTO, R.M. et al. "Comparative study of the rapid burning with the traditional burning in the properties of ceramic materials of clayey base", Cerâmica, v. 55, n. 333, pp. 100-105, Mar. 2009.

[4] SILVA, A. G. P.; ALVES JUNIOR, C., "Rapid sintering: its application, analysis and relationship with innovative sintering techniques", Cerâmica, v. 44, n. 290, pp. 225-232, Dez. 1998.

[5] MORAIS, M.D.P.; MACEDO, R.S.; RAPOSO, C.M.O., "Preparação e caracterização de sistemas chamote/argila visando o reaproveitamento de descartes industriais", Cerâmica, v. 61, n. 358, pp. 206-212. 2015.

[6] SILVA, R.G.; SILVA, V.P., "Produção mais limpa: contributos teórico-práticos para a sustentabilidade da cerâmica vermelha", Cerâmica, v. 63, n. 368, pp. 494-507. 2018.

[7] ALMEIDA, P.H.S.; FRANCO, J.M.; TAVARES, C. R. G, "Influência do tipo de argila no processo de solidificação/estabilização de lodo têxtil”, Cerâmica, v. 61, n. 357, pp. 137-144. 2015.

[8] ARAÚJO, F.C., Scalize, P.S., Albuquerque, A.J.C., et al., "Caracterização física do resíduo de uma estação de tratamento de água para sua utilização em materiais de construção", Cerâmica, v. 61, n. 360, pp. 450456. 2015.

[9] AREIAS, I.O.R., VIEIRA, C.M.F., MANHÃES, R.S., et al. "Incorporação de lodo da estação de tratamento de esgoto (ETE) em cerâmica vermelha”, Cerâmica, v. 63, n. 367, pp. 343-349. 2018

[10] BRUXEL, F. R., OLIVEIRA, E.C., STULP, S., et al., "Study of the gem residue (sludge) addition in bulk red ceramics", Cerâmica, v. 58, n. 346, pp. 211-215. 2012.

[11] CARREIRO, M.E.A., SANTOS, R.C., SILVA, V.J., et al., "Resíduo de quartzito-matéria-prima alternativa para uso em massas de cerâmica estrutural", Cerâmica, v. 62, n. 362, pp. 170-178. 2016.

[12] MENDES, T.M., MORALES, G., REIS, P.J., "Use of basaltic waste as red ceramic raw material", $C e$ râmica, v. 62, n. 362, pp. 157-162. 2016.

[13] COUTINHO, N.C., VIEIRA, C.M.F., "Caracterização e incorporação de cinza de resíduo sólido urbano em cerâmica vermelha”, Cerâmica, v. 62, n. 363, pp. 249-255. 2016.

[14] ROSIÈRE, C.A., CHEMALE JR, F., GUIMARÃES, M. L. V., "Um modelo para a evolução microestrutural dos minérios de fero do Quadriláteo Ferrífero. Parte I - Estruturas e recristalização", Geonomos, v. 1, n. 1/2. 1993 .

[15] JESUS ESPÓSITO, T., DUARTE, A. P., "Classificação de barragens de contenção de rejeitos de mineração e de resíduos industriais em relação a fatores de risco", Rem: Revista Escola de Minas, v. 63, n. 2. 2010.

[16] ROCHA, R.D.C., ZOREL JR, H.E., LANDO, T., "Utilização de planejamento experimental no estudo para imobilização de lodo galvânico em cerâmica vermelha para minimização de impactos ambientais", $C e$ râmica, v. 63, n. 365, pp. 1-10. 2018.

[17] SANTOS, P.S., Ciência e tecnologia de argilas, 2 ed., São Paulo, Editora Edgard Blücher, 1989.

[18] ROVERI, C.D., ZANARDO, A., MORENO, M. M. T., "Variação da cor e propriedades cerâmicas com o aumento da temperatura de queima de uma argila proveniente da formação Corumbataí, região de Piracicaba (SP)", Cerâmica, v. 53, n. 328, pp. 436. 2007.

[19] CÂMARA, A.P.C., MEDEIROS, L.C., DE MACEDO, D.A., et al., "Caracterização Físico-mecânica e Ambiental de Cerâmica Estrutural com Imobilização do Íon Manganês”, Cerâmica Industrial, São Paulo, v.18, n. 1, pp. 39-42. Jan/Fev. 2013.

[20] KLEIN, C., DUTROW, B., Manual de Ciência dos Minerais, 23 ed., Porto Alegre, Bookman. 2012. 
[21] DAMIANI, J. C., PEREZ, F., MELCHIADES, F. G., et al., "Coração Negro em Revestimentos Cerâmicos: Principais Causas e Possíveis Soluções”, Cerâmica Industrial, São Paulo, v. 6, n. 2, pp.12-16. Mar/Abr. 2001.

[22] DA SILVA, F.L., ARAÚJO, F.G.S., TEIXEIRA, M.P., et al., "Study of the recovery and recycling of tailings from the concentration of iron ore for the production of ceramic", Ceramics International, v. 40, pp.16085-16089. 2014.

[23] YELLISHETTY, M., KARPE, V., REDDY, E. H., et al., "Reuse of iron ore mineral wastes in civil engineering constructions: A case study. Resources", Conservation and Recycling, v. 52, n. 11, pp.1283-1289. 2008.

[24] DAS, S.K., KUMAR, S., RAMACHANDRARAO, P., "Exploitation of iron ore tailing for the development of ceramic tiles". Waste Management, v. 20, n.8, pp.725-729. 2000.

[25] DEPARTAMENTO NACIONAL DE ESTRADAS DE RODAGEM (DNER), DNER-ME 05/94 - Solos: Análise Granulométrica, Brasília. 1994.

[26] BRITO, I.P., ALMEIDA, E.P., NEVES, G.A., et al., “Avaliação de novos depósitos de argilas do estado da Paraíba visando sua aplicação como matérias-primas cerâmicas”, Cerâmica, v. 61, n. 360, pp.391-398. Out/Dez. 2015.

[27] MUNSELL SOIL COLOR COMPANY. Munsell soil color chats, Baltimore, Macbeth Division of Kollmorgen Corporation. 2009.

[28] AZEVEDO, A.G.S., STRECKER, K., LOMBARDI, C.T., "Produção de geopolímeros à base de metacaulim e cerâmica vermelha", Cerâmica, v. 64, n. 371, pp. 388-396. 2018.

[29] ASSOCIAÇÃO BRASILEIRA DE NORMAS TÉCNICAS (ABNT), NBR 7170: Tijolo maciço cerâmico para alvenaria, Rio de Janeiro. 1983.

[30] ASSOCIAÇÃO BRASILEIRA DE NORMAS TÉCNICAS (ABNT), NBR 15270-1: Componentes cerâmicos, Rio de Janeiro. 2005.

\section{ORCID}

Igor Brumano Coelho Amaral BernatVinolas Prat Arlete Barbosados Reis https://orcid.org/0000-0003-3580-0289

https://orcid.org/0000-0002-0002-2811

http://orcid.org/0000-0002-0721-2810 